\title{
Notes on Beltane Cakes
}

\section{Rev. Walter Gregor LL. D.}

To cite this article: Rev. Walter Gregor LL. D. (1895) Notes on Beltane Cakes, Folklore, 6:1, 2-5, DOI: $10.1080 / 0015587 X .1895 .9720275$

To link to this article: http://dx.doi.org/10.1080/0015587X.1895.9720275

$$
\text { 曲 Published online: } 14 \text { Feb } 2012 .
$$

$\sqrt{6}$ Submit your article to this journal $₫$

Џll Article views: 6

Q View related articles ¿ 
Mr. A. J. Evans read a paper on the Rollright Stones and their Folk-Lore (infra p. 6); and a discussion followed, in which the President, Mr. Nutt, Mr. Kirby, Dr, Corney, Mr. Clodd, and Mr. Raynbird took part:

Mr. Evans having replied, a hearty vote of thanks was accorded to him for his paper.-

\section{NOTES ON BELTANE CAKES.}

BY REV, WALTER GREGOR, LL.D.

At Achterneed, near Strathpeffer, Ross-shire, on the first day of May the children received each an egg and a cake. With these they. went to the hill, as many at times as twenty and thirty in company. They gathered material, formed a bonfire, and roasted the eggs in the ashes. - Before placing the egg in the ashes, each child put a mark on it so as to be able to identify it when taken from the ashes. The egg and the cake were eaten. The cake was baked between nine and ten o'clock in the morning. It was kneaded entirely in the hand, and not on a board or table like common cakes. It was "fired" or baked in front of the peat fire on the hearth' supported by a stone. After being so baked it was put into the child's hand, and not on any table or dish. It must never be put from the hand except to be baked in front of the fire. If laid on anything it was then nothing more than an ordinary bannock. It was called " tcharnican" (spelt phonetically), because it was made wholly in the hand. The word means "hand-cake.". Those now sent were 
baked by a native of the parish of Fodderty, who is now eighty-three years of age. One of them was baked in my presence.

I append statements relating to Beltane cakes collected at other places, with the names of my informants.

Bannocks were baked the evening before Beltane, the first day of May (O.S.), and were called Beltane bannocks. They were made of oatmeal in the usual way, but they were washed over or "watered" with a thin batter composed of whipped egg, milk or cream, and a little oatmeal. Before being laid on the "brannithr" (Keith), "branner" (other districts), i.e. gridiron, the upper side was rubbed over with this batter. When the underside was sufficiently baked or "fired," the bannock was turned, and the underside was now rubbed over with the batter. The bannock was then allowed to hang over the fire on the gridiron till fully baked. On Beltane about mid-day the young folks, each with a bannock, went to the rocks or high grounds, and rolled them down. If a bannock broke in the rolling, the one to whom it belonged would come to some disaster or die before next Beltane. They ate them, but left a "bittie" to the "cuack" or cuckoo. They carried a piece home, and placed it under the pillow in the sweetheart's name, to find out if dreams would reveal the future as to marriage.

Eggs were not used in baking the Baptismal and Christmas bannocks.

Janet Davidson (aged 81), Kingussie.

The same custom was followed in Daviot, Strathnairn, but with this difference, that the bannocks were baked any time during the day before. It was accounted unlucky if anyone's bannock broke in the baking.

Mrs. Robertson (aged 72), born in Daviot, now at Lynnchat, Alvie. 
In Dyke the bannock was baked very thick, and the upper side was smeared or "watered" with a batter made of whisked eggs, milk, and oatmeal. A peat on fire through and through, quite without smoke and clear, was held over the upper side till the "watering" was dry. The bannock was then turned, and the side that had been under next the fire and was baked was now washed over with the batter, and the bannock was allowed to hang over the fire till it was fully baked. One was prepared for each of the family. On Beltane all the family went together to roll the bannocks. They afterwards ate them.

Mrs. Munro, Dyke.

In parts of Easter Ross, the cattle were all put out to pasture on Beltane, and each herd received a bannock, called the Beltane bannock, when setting out to the pasture with the animals.

G. Maclean (aged 73).

In Corgarff, the bannock was about four inches in diameter and washed over with whisked egg. One was made for each member of the family, and marked so that it might be known for whom it was intended. : After four o'clock p.m. all the inmates of the house went to the top of a rising ground or slope and rolled the bannocks down. Omens of good or bad luck or of death were drawn from the way in which they rolled. If a bannock fell before it reached the bottom, some evil awaited its owner within the year. If one broke, its owner was to die before the same time next year. Each one rolled the bannock three times.

J. Farquharson, Corgarf.

When the breeding ewes were "clippit," or shorn, they were milked. From the milk was made a cheese, and this cheese was kept till the first day of May. On the morning 
of that day an oatmeal bannock was baked by the goodwife for each member of the household. An egg was whipped and spread over it, first on one side and then on the other, in the act of being "fired" or baked. When it was laid on the gridiron the sign of the cross was made over it, as also when it was turned. About nine o'clock a.m. the goodman cut the cheese with the kitchen knife, after making the sign of the cross over it. A slice of cheese was laid on a piece of each bannock for each one of the household. Each piece of each bannock and each slice of cheese had to be eaten by each member of the family before sunset. The remainder of the "kebback," or cheese, was kept till Lammas (Ist of August), when the whole had to be eaten before sunset, even although the dogs had to get part of it. No special bannock was baked for that day.

H. Macintosh, Corgarff.

On two hills in the Highlands of Aberdeenshire the Banshee had to be propitiated by the traveller over the hills. This was done by placing near a well on each hill a barley-meal cake marked on one side by a round figure 0 . If the cake was not left death or some dire calamity befell the traveller. On one occasion a woman had to cross one of the hills. She neglected to leave the customary offering. She paid the penalty. She died at a cairn not far from the well. The cairn bears the name of Cairn Alshish, i.e. Elspet's Cairn. .

The victim on the other hill was a man. He had omitted to pay the usual tribute, and the omission cost him his life. 